\title{
UPAYA MENINGKATKAN AKTIFITAS DAN HASIL BELAJAR SISWA PADA MATA PELAJARAN MATEMATIKA DENGAN PENDEKATAN KONTEKSTUAL (CTL) DI KELAS V SDN 060959 BELAWAN
}

\author{
Ester Julinda Simarmata
}

Surel: ejulinda@ymail.com

\begin{abstract}
ABSTRAK
Penelitian ini bertujuan untuk: (1) Untuk meningkatan aktifitas belajar siswa melalui pendekatan Kontekstual materi Bangun Datar di kelas V. (2) Untuk meningkatan hasil belajar siswa melalui pendekatan Kontekstual materi Bangun Datar. Teknik pengumpulan data melalui pengamatan terhadap tes hasil belajar, aktivitas belajar siswa. Berdasarkan hasil belajar siswa siklus I dan siklus II diketahui bahwa nilai rata-rata tes evaluasi dari 67,17 menjadi 86,96. (3) Ketuntasan siswa dalam belajar matematika melalui pendekatan Kontekstual pada materi Bangun Datar terjadi peningkatan. Peningkatan yang terjadi antara ketuntasan belajar siswa pada siklus I dengan siklus II sebesar 22,29\%. Berdasarkan penelitian ini, maka disarankan guru matematika SDN 060959 Belawan mengajarkan bangun datar melalui pendekatan Kontekstual.
\end{abstract}

Kata Kunci: Pendekatan Kontekstual, Aktivitas, Hasil Belajar

\section{PENDAHULUAN}

Masalah utama dalam pembelajaran pada pendidikan formal dewasa ini adalah masih rendahnya daya serap peserta didik. Hal ini tampak dari rerata hasil belajar peserta didik yang senantiasa masih sangat memprihatinkan. Di pendidikan hasil belajar merupakan tolok ukur yang paling mendasar, yaitu semakin baiknya hasil belajar yang dicapai dalam dunia pendidikan maka semakin besar kemungkinan tercapainya tujuan pendidikan, misalnya saja dalam pembelajaran matematika.

Pembelajaran matematika merupakan ilmu yang berfungsi untuk mengembangkan kemampuan menghitung dan mengukur dengan menggunakan rumus matematika dan turunannya. Proses belajar mengajar matematika merupakan suatu kegiatan yang mengandung serangkaian persiapan guru dan siswa atas dasar hubungan timbal balik yang berlangsung dalam situasi edukatif untuk mencapai tujuan tertentu. Dalam proses belajar mengajar terdapat adanya satu kesatuan yang tidak dapat dipisahkan antara guru yang mengajar dengan siswa yang belajar.

Matematika merupakan ilmu pengetahuan yang sangat berguna dalam menyelesaikan permasalahan kehidupan sehari-hari. Tujuan pendidikan matematika pada jenjang pendidikan dasar adalah menekankan pada nalar dan pembentukan kepribadian (sikap) siswa agar dapat

Dosen Universitas Katolik Indonesia 
menggunakan atau menerapkan matematika dalam kehidupannya sehari-hari. Dengan begitu pelajaran matematika menjadi mata pelajaran yang sangat penting bagi jenjang pendidikan dan kehidupan sehari-hari siswa.

Dari hasil pengamatan yang dilakukan oleh peneliti di SDN 060959 Belawan dapat diketahui bahwa kemampuan siswa dalam menyelesaikan soal-soal masih rendah terutama dalam menyelesaikan soal-soal dengan bentuk soal essay test dan dari seluruh siswa kelas $\mathrm{V}$ hanya sekitar $50 \%$ saja yang dapat menyelesaikan soal dengan baik dan benar.

Salah satu upaya

meningkatkan pemahaman siswa terhadap pelajaran matematika adalah guru harus menguasai materi yang diajarkan dan menyesuaikan dengan pendekatan pembelajaran agar aktivitas dan hasil belajar siswa dapat meningkat dan dapat mengatasi kesulitan belajar siswa dalam mempelajari konsep matematika.

\section{Dengan}

pendekatan

kontekstual siswa diajak untuk aktif bergerak dan mengerjakan soal-soal maupun tugas-tugas yang diberikan oleh guru dan untuk membuat siswa dapat memahami dan mengerti materi yang telah diajarkan. Pendekatan kontekstual mendasarkan diri pada kecenderungan pemikiran tentang belajar bahwa belajar tidak hanya sekedar menghafal, tetapi siswa harus mengkonstruksikan pengetahuan di benak mereka sendiri. Siswa belajar dengan mengalami, karenanya mereka dituntut untuk bisa mencatat sendiri pola-pola bermakna dari pengetahuan baru, dan bukan diberi begitu saja oleh guru. Siswa perlu dibiasakan memecahkan masalah, menemukan sesuatu yang berguna bagi dirinya, dan bergelut dengan ideide.

Proses belajar dapat mengubah struktur otak, dimana perubahan struktur otak itu berjalan terus seiring dengan perkembangan organisasi pengetahuan dan keterampilan seseorang. Untuk itu perlu dipahami, pendekatan belajar yang salah dan terus-menerus digunakan akan mempengaruhi struktur otak, yang pada akhirnya mempengaruhi cara seseorang berprilaku.

Dari uraian tersebut, peneliti merasa perlu meneliti tentang "Upaya Meningkatkan Aktivitas Dan Hasil Belajar Siswa Pada Mata Pelajaran Matematika Dengan Pendekatan Kontekstual (CTL) Di Kelas V SDN 060959 Belawan."

Pengertian pembelajaran kontekstual (Contextual Teaching and Learning) menurut Nurhadi (2002:1) adalah konsep belajar yang membantu guru mengaitkan antara materi dengan yang diajarkannya dengan situasi dunia nyata siswa dan mendorong siswa membuat hubungan antar pengetahuan yang dimilikinya dengan penerapan dalam kehidupan mereka sehari-hari, dengan 
melibatkan tujuh komponen utama pembelajran efektif, yakni: konstruktivisme (Constructivism), menemukan (Inquiry), bertanya (Questioning), masyarakat belajar (learning Community), pemodelan (Modelling), refleksi (reflection) dan penilaian sebenarnya (Authentic Assessment).

Pendekatan kontekstual

(Contextual Teaching and Learning

(CTL) merupakan konsep belajar yang menghendaki agar guru mengaitkan antara materi yang diajarkannya dengan situasi dunia nyata siswa, dan mendorong siswa membuat hubungan antara pengetahuan yang dimilikinya dengan penerapanya dalam kehidupan seharihari. Dengan konsep itu, hasil pembelajaran diharapkan lebih bermakna bagi siswa. Sebab pada dasarnya pendidikan merupakan proses untuk membantu manusia dalam mengembangkan potensi dirinya sehingga mampu menghadapi setiap perubahan yang terjadi.

Dalam kegiatan pembelajaran CTL, ciri pokok kegiatannya adalah peserta didik perlu mengerti apa makna belajar, apa manfaatnya, dalam status apa mereka dan bagaimana mencapainya. Mereka harus diberi kesadaran bahwa apa-apa yang mereka pelajari akan berguna bagi kehidupannya kelak. Dengan cara ini, diharapkan mereka dapat memposisikan dirinya bahwa mereka memerlukan suatu bekal bagi kehidupannya nanti. Karena itu, mereka harus mempelajari apa yang bermanfaat bagi dirinya dan berupaya mencapainya. Tidak seperti kenyataan, bahwa dari observasi peneliti menunjukkan bahwa tingkat penguasaan peserta didik dalam matematika di sekolah masih kurang. Hal ini sangat memprihatinkan banyak pihak, terutama yang menaruh perhatian dan minat khusus pada bidang ini. Anggapan masyarakat khususnya di kalangan pelajar, matematika masih merupakan mata pelajaran sulit, membingungkan dan bahkan sangat ditakuti oleh sebagian besar yang mempelajarinya.

Tujuan dari penelitian ini adalah penggunaan metode pembelajaran (Contextual Teaching and Learning (CTL) untuk meningkatkan hasil belajar matematika siswa.

\section{METODE PENELITIAN}

Penelitian ini dilaksanakan di SDN 060959 Belawan, J1 Cianjur Belawan 2 (Gg. 7).

Subjek penelitian adalah seluruh siswa kelas V SDN 060959 Belawan yang berjumlah 23 orang. Siswa laki-laki berjumlah 9 orang dan siswa perempuan berjumlah 14 orang. Objek penelitian ini adalah upaya meningkatkan aktivitas dan hasil belajar siswa pada mata pelajaran matematika dengan menggunakan pendekatan kontekstual pada materi bangun datar dan alternatif tindakan 
yang diberikan sebagai upaya untuk meningkatkan hasil belajar matematika siswa kelas $\mathrm{V}$ SDN 060959 Belawan.

Dalam penelitian ini beberapa karakteristik objek penelitian yang dikaji adalah keluasan sumber belajar yang digunakan, keterampilan siswa dalam mendemonstrasikan, kemampuan kreatifitas siswa dalam mempresentasikan hasil diskusi dan respon siswa terhadap desain pembelajaran.

Penelitian ini langsung dilakukan di dalam kelas meliputi kegiatan pelaksanaan penelitian tindakan kelas berupa refleksi awal dan observasi untuk mengidentifikasi permasalahan yang terjadi di kelas. Pelaksanaan penelitian tindakan kelas dilakukan selama tiga siklus. Desain penelitian yang dilaksanakan adalah desain penelitian tindakan kelas menggunakan Model Penelitian Tindakan Menurut Arikunto.

Teknik pengumpulan data dilakukan melalui tes, observasi dan catatan lapangan. Tes digunakan untuk mengetahui sejauh mana tingkat penguasaan siswa terhadap materi bangun datar dan observasi berupa pengamatan terhadap kegiatan siswa dan perubahan yang terjadi pada saat dilakukannya pemberian tindakan dalam pernyataan yang dicatat pada saat pembelajaran berlangsung.

Teknik analisis data dilakukan secara kuantitatif berdasarkan tes kemampuan dan observasi.

\section{HASIL DAN PEMBAHASAN}

Hasil penelitian yang disajikan meliputi: persentase aktivitas belajar dan persentase ketuntasan belajar selama 2 (dua) siklus.

\section{Tabel Hasil Pengamatan Aktivitas} Siswa Siklus I

\begin{tabular}{|c|c|c|}
\hline Pertemuan & $\begin{array}{c}\text { Rata-rata } \\
\text { Skor }\end{array}$ & $\begin{array}{c}\text { Kriteria } \\
\text { Penilaian }\end{array}$ \\
\hline Pertama & 77 & Cukup \\
\hline Kedua & 79 & Cukup \\
\hline Rata-rata Siklus I & 78 & Cukup \\
\hline
\end{tabular}

Rata-rata dari aktivitas siswa terhadap pembelajaran pada pertemuan pertama sebesar 77 dengan kategori cukup, dan pada pertemuan kedua sebesar 79,23 dengan kategori cukup. Dengan demikian dapat disimpulkan bahwa aktifitas siswa dalam melaksanakan proses pembelajaran melalui CTL pada siklus I berlangsung baik dengan kategori cukup.

\section{Tabel Hasil Pengamatan Aktivitas Siswa Siklus II}

\begin{tabular}{|c|c|c|}
\hline Pertemuan & $\begin{array}{c}\text { Rata-rata } \\
\text { Skor }\end{array}$ & $\begin{array}{c}\text { Kriteria } \\
\text { Penilaian }\end{array}$ \\
\hline Pertama & 81 & Baik \\
\hline Kedua & 85 & Baik \\
\hline $\begin{array}{c}\text { Rata-rata } \\
\text { Siklus II }\end{array}$ & 83 & Baik \\
\hline
\end{tabular}

Berdasarkan data observasi dari hasil pengamat pada tabel 4.3 diatas, diketahui bahwa rata-rata skor dari aktivitas siswa terhadap pembelajaran pada pertemuan pertama sebesar 81 dengan kategori cukup, dan pada pertemuan kedua 
sebesar 85 dengan kategori baik. Dengan demikian dapat disimpulkan bahwa aktifitas siswa dalam melaksanakan proses pembelajaran melalui CTL pada siklus II berlangsung baik.

Jika dilihat dari aspek aktivitas siswa maka terdapat perubahan dari pada siklus I (satu). Siswa pada siklus II melalui CTL dalam kategori "Baik" cuman masih ada beberapa siswa belum berani dalam menggungkapkan pendapat yang siswa milikinya, mereka masih takut mengungkapkan pendapat, Tapi ini sudah banyak mengalami perubahan dari pada di siklus I, banyak siswa yang sudah mulai berani beragumen atau berpendapat pada siklus II ini. Mungkin ini terjadi karena di dalam pendekatan CTL pada pembelajaran matematika guru melibatkan siswa secara aktif dalam mengungkapkan pendapatnya.

\section{Tabel Hasil Rekapitulasi Tes Evaluasi Siklus I}

\begin{tabular}{|c|c|c|c|}
\hline NO & $\begin{array}{c}\text { Partisipasi } \\
\text { Siswa }\end{array}$ & $\begin{array}{c}\text { Banyaknya } \\
\text { Siswa }\end{array}$ & Persentase \\
\hline 1 & Nilai $<65$ & 8 & $34,78 \%$ \\
\hline 2 & Nilai $\geq 65$ & 15 & $65,21 \%$ \\
\hline 3 & $\begin{array}{c}\text { Tuntas } \\
\text { Belajar }\end{array}$ & 15 & $65,21 \%$ \\
\hline 4 & $\begin{array}{c}\text { Tidak Tuntas } \\
\text { Belajar }\end{array}$ & 8 & $34,78 \%$ \\
\hline 5 & $\begin{array}{c}\text { Nilai rata- } \\
\text { rata kelas }\end{array}$ & $\begin{array}{c}\text { Ketuntasan } \\
\text { Belajar } \\
\text { Klasikal }\end{array}$ & $\frac{15}{23} x 100 \%=65,21 \%$ \\
\hline
\end{tabular}

Berdasarkan data pada tabel di atas, dapat dilihat kemampuan siswa dalam menyerap materi bangun datar. Dari 23 siswa terdapat 15 siswa $(65,21 \%)$ yang tuntas individual yaitu siswa yang mendapat nilai $\geq 65$ dengan rata-rata 77,00 sedangkan siswa yang tidak tuntas indifidu terdapat 8 siswa $(34,78 \%)$ yaitu siswa yang mendapat nilai < 65 dengan rata-rata 48,75. Nilai rata-rata kelas adalah 67,17 dengan nilai terendah 40 dan nilai tertinggi 85. Banyaknya siswa yang tuntas individual adalah 15 siswa, dengan kata lain ketuntasan belajar klasikalnya mencapai $65,21 \%$. Tingkat persentase ketuntasan belajar klasikal direncanakan minimal adalah $85 \%$ dari jumlah siswa yang mengikuti tes.

Untuk mencapai tingkat persentase ketuntasan belajar klasikal tersebut direncanakan yaitu minimal $85 \%$, maka terdapat minimal $19,79 \%$ dari jumlah siswa yang mengikuti tes sebagai kekurangannya. Hal ini akan menjadi perhatian sebagai bahan refleksi untuk tindak lanjut ke siklus II.

Tabel Hasil Rekapitulasi Tes Evaluasi Siklus II

\begin{tabular}{|c|c|c|c|}
\hline No & $\begin{array}{c}\text { Partisipasi } \\
\text { Siswa }\end{array}$ & $\begin{array}{c}\text { Banyaknya } \\
\text { Siswa }\end{array}$ & Persentase \\
\hline 1 & Nilai $<70$ & 3 & $13,04 \%$ \\
\hline 2 & Nilai $\geq 70$ & 20 & $87,50 \%$ \\
\hline 3 & $\begin{array}{l}\text { Tuntas } \\
\text { Belajar }\end{array}$ & 20 & $87,50 \%$ \\
\hline 4 & $\begin{array}{c}\text { Tidak } \\
\text { Tuntas } \\
\text { Belajar }\end{array}$ & 3 & $13,04 \%$ \\
\hline
\end{tabular}




\begin{tabular}{|c|c|c|}
\hline 5 & $\begin{array}{c}\text { Nilai rata- } \\
\text { rata kelas }\end{array}$ & 86,96 \\
\hline 6 & $\begin{array}{c}\text { Ketuntasa } \\
\text { n belajar } \\
\text { klasikal }\end{array}$ & $\frac{20}{23} \times 100 \% 6=87,50 \%$ \\
\hline
\end{tabular}

Berdasarkan data pada Tabel 4.7 di atas, dapat dilihat kemampuan siswa dalam menyerap materi layanglayang dan trapesium. Dari 23 siswa terdapat 20 siswa $(86,95 \%)$ yang tuntas individual yaitu siswa yang mendapat nilai $\geq 70$ dengan rata-rata 87,50 sedangkan siswa yang tidak tuntas individual terdapat 3 siswa $(13,04 \%)$ yaitu siswa yang mendapat nilai < 70 dengan rata-rata 56,66. Nilai rata-rata kelas adalah 86,96 dengan nilai terendah 50 dan nilai tertinggi 100. Banyaknya siswa yang tuntas individual adalah 20 siswa, dengan kata lain ketuntasan belajar klasikalnya mencapai $87,50 \%$. Tinggkat persentase ketuntasan belajara klasikal direncanakan minimal adalah $85 \%$ dari jumlah siswa yang mengikuti tes. Dengan demikian indikator keberhasilan sudah tercapai dan tindakan tidak dilanjutkan ke siklus berikutnya.

Beberapa kegiatan yang dilakukan peneliti dan rekan sejawat dalam merefleksi siklus II, di antaranya adalah sebagai berikut:

Di akhir pelaksanaan siklus II, guru mengadakan tes evaluasi untuk mengukur kemampaun siswa dalam memahami materi yang telah disampaikan. Berdasarkan hasil analisis data bahwa hasil belajar siswa pada materi layang-layang dan trapesium diperoleh dari 23 siswa terdapat 20 siswa yang tuntas individual dengan persentase $87,50 \%$, sedangkan siswa yang tidak tuntas individual hanya terdapat 3 siswa dengan persentase $13,04 \%$. Nilai ratarata kelas adalah 86,96 dengan nilai terendah 50 dan nilai tertinggi 100 .

Berdasarkan analisis data di atas, dapat dikatakan bahwa pembelajaran pada siklus II sudah mencapai ketuntasan klasikal pada hasil belajar matematika siswa. Dari temuan di atas dapat dinyatakan penggunaan pendekatan kontekstual (CTL) pada siklus II terjadi peningkatan dari siklus-siklus sebelumnya.

Dengan demikian, banyaknya siswa yang tuntas imdividual adalah 20 siswa, dengan kata lain ketuntasan belajar klasikalnya mencapai $87,50 \%$. Tingkat persentase ketuntasan belajar klasikal direncanakan minimal $85 \%$ dari jumlah siswa yang mengikuti tes. Berdasarkan hasil tes evaluasi pada siklus II, hasil belajar siswa mengalami peningkatan yang signifikan sehingga dapat disimpulkan bahwa pelaksanaan pembelajaran pada siklus II telah tercapai dan memenuhi indikator keberhasilan dan tidak perlu dilanjutkan pada siklus berikutnya.

\section{Pembahasan}

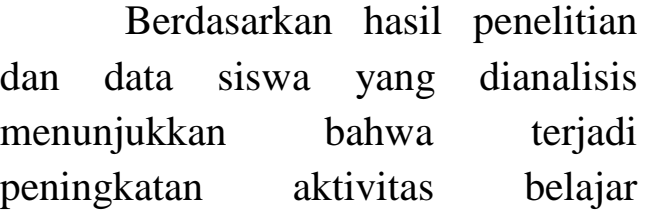


matematika siswa melalui penggunaan pendekatan kontekstual (CTL). Aktivitas belajar matematika siswa siklus I dengan rata-rata sebesar 78 masih dalam kategori "cukup", dan sedangkan aktivitas belajar matematika siswa siklus II sebesar 83 sudah dalam kategori "baik". Dengan demikian, aktivitas siswa terhadap terhadap terhadap belajar matematika dan penggunaan pendekatan kontekstual (CTL) sudah dalam kategori "baik".

Berdasarkan data dan hasil penelitian yang telah dianalisis menunjukkan bahwa terjadi peningkatan hasil belajar matematika melalui penggunaan pendekatan kontekstual (CTL). Hasil tes evaluasi siswa pada materi bangun datar menunjukkan peningkatan pada setiap siklusnya. Pada siklus I diperoleh $65,21 \%$ atau sebanyak 15 siswa dari 23 siswa yang telah memenuhi KKM yang telah ditentukan. Dan selanjutnya pada siklus II diperoleh tingkat hasil belajar siswa sebesar $87,50 \%$ atau sebanyak 20 siswa dari 23 yang telah memenuhi KKM yang telah ditentukan.

Berdasarkan pada analisis data hasil tes, ketuntasan belajar siswa dalam menyelesaikan soal materi pecahan mengalami peningkatan yang maksimal pada setiap siklusnya. Pada siklus I dan II terjadi peningkatan sebesar 22,29\% atau sebanyak 20 orang siswa yang tuntas belajar dari 23 siswa yang telah memenuhi KKM yang telah ditentukan. Pada siklus II peningkatan ketuntasan belajar siswa menjadi $87,50 \%$.

\section{SIMPULAN}

Berdasarkan hasil penelitian dan pembahasan yang telah diuraikan pada BAB IV, dapat diperoleh beberapa kesimpulan sebagai berikut:

1. Aktifitas belajar siswa siklus I dengan rata-rata persentase skor sebesar $78 \%$ dengan kategori baik dan aktifitas siswa pada siklus II sebesar $83 \%$ juga masih dalam kategori baik. Berdasarkan hasil tersebut maka terjadi peningkatan sebesar 5\%.

2. Hasil belajar siswa siklus I dan siklus II diketahui bahwa nilai rata-rata tes evaluasi dari 67,17 menjadi 86,96 , skor terendah dari 40,00 menjadi 50,00 dan skor tertinggi dari 85,00 menjadi 100,00 .

3. Persentase ketuntasan belajar siswa pada siklus I sebesar $65,21 \%$, sedangkan pada siklus II ketuntasan belajar siswa sebesar $87,50 \%$. Dengan demikian, peningkatan yang terjadi antara ketuntasan belajar siswa pada siklus I dengan siklus II sebesar $22,29 \%$.

Berdasarkan penelitian yang telah dilakukan, maka saran yang dapat diberikan adalah sebagai berikut: 
1. Guru dapat menerapkan pendekatan Kontekstual dalam rangka meningkatkan kualitas pembelajaran.

2. Siswa menjadi lebih berani untuk bertanya apabila masih ada yang tidak dipahami, lebih berani menjawab pertanyaan, dan berani ke depan kelas untuk mengerjakan soal yang diberikan. Dengan demikian apabila aktifitas belajar siswa seperti yang dikatakan diatas dapat meningkatkan hasil belajar siswa tersebut.

3. Di kelas V SDN 060959 Belawan, pendekatan Kontekstual yang telah dilaksanakan dapat meningkatkan hasil, aktifitas belajar serta respon siswa terhadap pembelajaran matematika.

4. Jika diterapkan pendekatan Kontekstual ini yang dilakukan secara berkelompok, maka guru diharuskan memberikan bimbingan terbatas pada siswa saat melakukan diskusi kelompok sehingga siswa benarbenar memanfaatkan waktu dan memahami materi dengan baik.

\section{DAFTAR RUJUKAN}

Arikunto, Suharsimi. 2002. Prosedur Penelitian Suatu Pendekatan Praktek. Jakarta: Rineka karya.
Bahri, Djamarah, Syaiful. 2008. Psikologi Belajar. Jakarta: Rineka Cipta.

Bahri, Djamarah, Syaiful, Zain, Aswan. 2010. Strategi Belajar Mengajar. Jakarta: Rineka Cipta.

Eveline, Nara. 2010. Teori Belajar dan Pembelajaran. Bogor: Ghalia Indonesia.

Halimah, Siti. 2008. Strategi Pembelajaran. $\quad$ Bandung: Citapustaka Media Perintis.

Hamalik, Oemar. 2007. Kurikulum Dan Pembelajaran. Bandung: Bumi Aksara.

Hardini, Puspitasari, 2012. Strategi Pembelajaran Terpadu: Teori, Konsep \& Implementasi. Yogyakarta: Familia.

Heruman. 2007. Model Pembelajaran Matematika. Bandung: Remaja Rosdakarya.

Johnson, Elaine B. 2007. Contextual Teaching and Learning. Bandung: MLC

Kunandar.2008. Langkah Mudah Penelitian Tindakan Kelas, Sebagai Pengembangan Profesi Guru. Jakarta: Rajawali Press.

Mudjiono, Dimyati. 2006. Belajar Dan Pembelajaran. Jakarta: Rineka Cipta.

Muhsetyo, Gatot. 2009. Pembelajaran Matematika 
SD. Jakarta: Universitas Terbuka.

Nurhadi. 2002. Pendekatan Kontekstual (Contextual Teaching and Learning). Departemen Pendidikan dan Kebudayaan.

Rusman. 2009. Model-Model Pembelajaran. Jakarta: Rajawali Pers.

Sagala, Syaiful. 2009. Konsep dan Makna Pembelajaran. Bandung: Alfabeta.

Sanjaya, Wina. 2005. Pembelajaran dalam Implementasi Kurikulum Berbasis Kompetensi. Jakarta: Kencana Prenada Media Group.

Sanjaya, Wina. 2009. Kurikulum dan Pembelajaran. Jakarta: Kencana.

Sanjaya, Wina. 2010. Strategi Pembelajaran Berorentasikan Standar Proses Pendidikan. Jakarta: Kencana.

Sardiman. 2011. Interaksi \& Motivasi Belajar Mengajar. Jakarta: PT Raja Grafindo Persada

Slameto. 2010. Belajar Dan FaktorFaktor yang Mempengaruhinya. Jakarta: Rineka Cipta.

S. Nasution. 2005. Berbagai Pendekatan Dalam Proses Belajar \& Mengajar. Jakarta: Bumi Aksara.
Subarinah. $2006 . \quad$ Inovasi Pembelajaran Matematika Sekolah Dasar. Jakarta: Depdiknas.

Sudjana, Nana. 2009. Penilaian Hasil Proses Belajar Mengajar. Bandung: Remaja Rosdakarya.

Syah, Muhibbin. 2010. Psikologi Pendidikan Dengan Pendekatan Baru. Bandung: Rosda.

Trianto. 2009. Mendesain Model Pembelajaran InovatifProgresif. Jakarta: Kencana. 